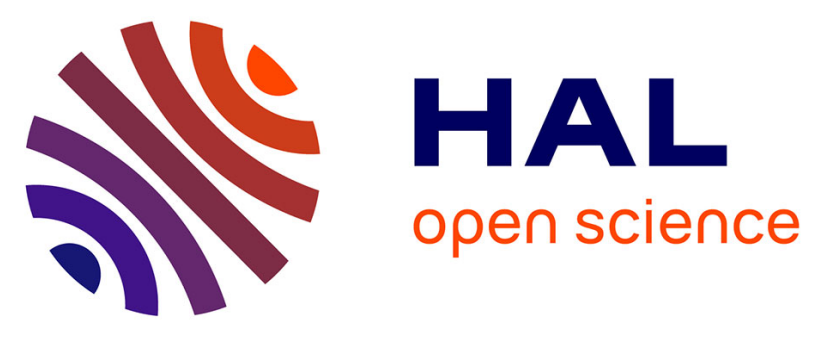

\title{
Compliance and enforcement: the Achilles heel of French water policy
}

\author{
Marielle Montginoul, Jean-Daniel Rinaudo, Charlotte Alcouffe
}

\section{To cite this version:}

Marielle Montginoul, Jean-Daniel Rinaudo, Charlotte Alcouffe. Compliance and enforcement: the Achilles heel of French water policy. Jean-Daniel Rinaudo; Cameron Holley; Steve Barnett; Marielle Montginoul. Sustainable groundwater management: a comparative analysis of French and Australian policies and implications to other countries, 24, Springer, pp.435-459, 2020, Global Issues in Water Policy, 978-3-030-32765-1. 10.1007/978-3-030-32766-8_23 . hal-02532168

\section{HAL Id: hal-02532168 https://hal.science/hal-02532168}

Submitted on 4 Apr 2020

HAL is a multi-disciplinary open access archive for the deposit and dissemination of scientific research documents, whether they are published or not. The documents may come from teaching and research institutions in France or abroad, or from public or private research centers.
L'archive ouverte pluridisciplinaire HAL, est destinée au dépôt et à la diffusion de documents scientifiques de niveau recherche, publiés ou non, émanant des établissements d'enseignement et de recherche français ou étrangers, des laboratoires publics ou privés. 


\title{
Chapter 23. Compliance and enforcement: the Achilles heel of French water policy
}

\author{
Marielle Montginoul ${ }^{1}$, Jean-Daniel Rinaudo ${ }^{2}$, Charlotte Alcouffe $^{1}$
}

1.UMR G-EAU, IRSTEA, Montpellier University, Montpellier, France.

2.BRGM (French Geological Survey), Montpellier University, Montpellier, France

Corresponding author: marielle.montginoul@irstea.fr

\begin{abstract}
This chapter examines the compliance and enforcement issues relating to groundwater policy in France. It is based on a review of existing grey and scientific literature and a series of interviews conducted by the authors with enforcement officers in 16 French counties. The chapter starts with a presentation of the existing regulations governing groundwater abstraction (Section 1), followed by a description of how the law enforcement agencies are organised (Section 2) and how they operate (Section 3). It then describes the infractions observed by regulators and analyses the factors that may explain compliance and non-compliance (Section 4). The problems that limit the effectiveness of enforcement are discussed.
\end{abstract}

Keywords: water crime; criminal enforcement; administrative sanction.

\section{Introduction}

The water policy implemented in France since the 1960s, is often presented as a model that has inspired European legislation, as well as legislation in other countries. Yet, its effectiveness is debatable: the environmental objectives set by European directives have not always been achieved. Many assessments have underlined that this situation could be due to problems of regulatory enforcement, which largely stem from the state's reluctance to prosecute violations of the law (Cour des comptes, 2010; Boutelet, 2014; Barone, 2018), as well as the difficulties of organising France's water police (Simoni et al., 2005; Legrand et al., 2015). 
In the field of quantitative management, a volumetric system for managing water resources, as laid down by the 2006 law on water and aquatic environments (see chapter 3), can only function if the vast majority of users comply with the existing regulations. All abstraction points, wells or boreholes must be declared and authorised and users must comply with the abstraction limits allocated to them (in terms of both flow and volume). To achieve this, several counties are jointly responsible for water policing, which aims to prevent and punish regulatory non-compliance. This chapter describes how the water police are organised in France and analyses the difficulties they face. In particular, it focuses on the issues of groundwater management in regions where agricultural water use is dominant. Indeed, most of the problems of law enforcement have been identified in the agricultural sector and concern abstraction for crop irrigation (Legrand et al., 2015).

This chapter reviews several official publications on the subject and draws on a series of semi-structured interviews conducted with environmental inspectors operating at county levels (Direction Départementale des Territoires). Interviews focussed on compliance and enforcement issues specifically related to groundwater. The objective was to identify the most frequent infractions, to understand the factors explaining non-compliance and to highlight the main difficulties met by law enforcement officers. The survey was conducted by telephone in 2016. It focused on 17 French counties (see Figure 23. 1) characterised by the prevalence of irrigated agriculture (over 10000 ha of irrigable land and $10 \%$ of the total land area irrigated), as well as the existence of major groundwater resources.

The chapter is organised as follows: the first section reviews the main regulatory obligations that apply to water users and focuses on the case of groundwater. Section 2 describes how the water police are organised. Section 3 attempts to describe the importance and nature of the infractions observed, based largely on the survey results. We then strive to highlight the factors that explain the scale of the problems of non-compliance. Section 5 describes the difficulties encountered by the water police and identifies possible courses of action to solve them. 


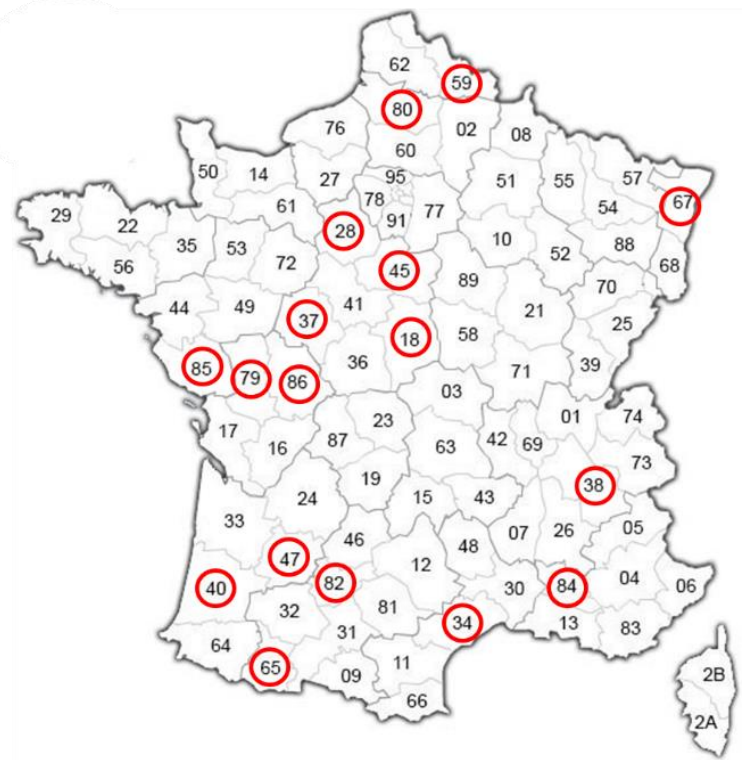

Figure 23. 1: Counties studied in the framework of the survey of the water policing services.

\section{Key regulatory provisions for groundwater ab- straction}

Groundwater users are subject to two main regulatory obligations relating to the construction of a well or borehole and to water abstraction.

\subsection{Administrative provisions for constructing wells and bore- holes}

When installations are constructed, the mining code stipulates that any underground structure exceeding a depth of 10 m must be declared to the regional environment agency (the DREAL, the Regional Directorate for Environment, Planning and Housing). In the declaration, the applicant (owner) must include the geological data gathered during the construction (the drilling $\log$ ). The underground installation must comply with the special building regulations set out in the environmental 
code ${ }^{65}$. These provisions apply irrespective of the intended use of the borehole (geothermics, water abstraction, exploratory drilling, etc.).

If the underground installation is intended for abstracting water, the owner must obtain a permit (the right to access the resource), according to the 1992 Water Act ${ }^{66}$. A permit is only obligatory if the user intends to abstract over $10000 \mathrm{~m}^{3}$ per year. For volumes of between 10000 and $200000 \mathrm{~m}^{3}$, the permit is automatically issued to the owner when they declare their installation to the government authority ( $D i$ rection Départementale des Territoires, DDT). The procedure is simplified and rapid, but it gives the administration the option to refuse an application. For volumes over $200000 \mathrm{~m}^{3}$ per year, the permit is granted after a more complex authorisation procedure, involving an assessment of the potential impact of abstraction on third parties and the environment. This allows state services to prohibit the construction of these larger installations or limit their pumping capacities in certain zones: ecologically sensitive areas, zones reserved for drinking water and overexploited zones. The abstraction permit is tied to the installation and is not time-limited. It is automatically transferred with the installation in the event of a sale.

\subsection{Administrative provisions for water abstraction}

Once the installation has been authorised, the user must apply for an abstraction permit. This specifies the restrictions applicable for the use of the installation. It indicates the flow rate and annual volume for abstraction. The annual volume may be expressed on a seasonal or monthly basis, depending on the existing local management systems (for further examples see chapters 13 and 18).

The authorisation procedure for abstraction also depends on the volume requested. When the volume abstracted is less than $10000 \mathrm{~m}^{3}$ per year, a declaration is not necessary, nor is an authorisation. For volumes between 10000 and 200000 $\mathrm{m}^{3}$ per year, a simple declaration suffices. In excess of $200000 \mathrm{~m}^{3}$ per year, the state services must authorise the abstraction. This allows the state to ensure that the total authorised volume does not exceed the volume that can be abstracted (see chapters 3 and 5). In restriction zones (ZRE in French), users must undergo the authorisation procedure if the pumping capacity (in flow rate) of the planned installation exceeds $8 \mathrm{~m}^{3} / \mathrm{hour}$.

\footnotetext{
${ }^{65}$ Decree of $11^{\text {th }}$ September 2003, which implements Decree $\mathrm{n}^{\circ}$ 96-102 of $2^{\text {nd }}$ February 1996 and lays down the general provisions applicable to drill holes, boreholes and the construction of wells or underground installations subject to a declaration pursuant to articles L. 214-1 to L. 214-3 of the environmental code and pertaining to category 1.1.1.0 of the nomenclature annexed in the modified Decree $n^{\circ}$ 93-743 of $29^{\text {th }}$ March 1993.

66 Article R214-1 of the environmental code.
} 
Table 23. 1: Regulatory provisions for groundwater use.

\begin{tabular}{|c|c|c|c|}
\hline & Type of abstraction & $\begin{array}{l}\text { Administrative } \\
\text { procedure govern- } \\
\text { ing boreholes or } \\
\text { wells }\end{array}$ & $\begin{array}{l}\text { Administrative } \\
\text { procedure for ab- } \\
\text { straction }\end{array}$ \\
\hline \multirow{4}{*}{$\begin{array}{l}\text { Outside wa- } \\
\text { ter restriction } \\
\text { zones (ZRE) }\end{array}$} & $\begin{array}{l}\text { Annual abstraction }<1000 \\
\mathrm{~m}^{3} / \mathrm{yr} \text {. (domestic use) }\end{array}$ & $\begin{array}{c}\text { Local council } \\
\text { declaration }\end{array}$ & Not applicable \\
\hline & $\begin{array}{l}\begin{array}{l}\text { Annual abstraction be- } \\
\text { tween } \\
1000 \mathrm{~m}^{3} / \mathrm{yr} \text {. and } 10000 \\
\mathrm{~m}^{3} / \mathrm{yr} \text {. }\end{array} \\
\end{array}$ & $\begin{array}{l}\text { Declaration to } \\
\text { DDT }\end{array}$ & Not applicable \\
\hline & $\begin{array}{l}\text { Annual abstraction be- } \\
\text { tween } \\
10000 \mathrm{~m}^{3} / \mathrm{yr} \text {. and } 200000 \\
\mathrm{~m}^{3} / \mathrm{yr} \text {. }\end{array}$ & $\begin{array}{l}\text { Declaration to } \\
\text { DDT }\end{array}$ & $\begin{array}{l}\text { Declaration to } \\
\text { DDT }\end{array}$ \\
\hline & $\begin{array}{l}\text { Annual abstraction } \\
>200000 \mathrm{~m}^{3} / \mathrm{yr} \text {. }\end{array}$ & $\begin{array}{l}\text { Application for } \\
\text { authorisation } \\
\text { (DDT) }\end{array}$ & $\begin{array}{l}\text { Application for } \\
\text { authorisation (DDT) }\end{array}$ \\
\hline In ZRE & $\begin{array}{l}\text { Pumping capacity exceed- } \\
\text { ing } 8 \mathrm{~m}^{3} / \mathrm{hr} \text {. }\end{array}$ & $\begin{array}{l}\text { Same procedure } \\
\text { as for outside the } \\
\text { ZRE }\end{array}$ & $\begin{array}{l}\text { Application for } \\
\text { authorisation } \\
\text { (DDT) }\end{array}$ \\
\hline
\end{tabular}

Until 2017, abstraction permits were issued individually to the user (for example, the owner or tenant farmer). They were renewed each year and the state had the possibility of varying the allocated volume, depending on the state of the water resource and the total volume requested by all the users (with authorised boreholes). Since 2017, the state issues a single authorisation to the water user groups (collective management organisations or OUGC in French, see Chapter 3), which are responsible for distributing the volume between their members. The state approves the distribution and checks that there is no environmental impact

\subsection{Temporary restrictions on water use}

When river flow rates or groundwater levels fall below a critical threshold, temporary restrictions on water use are introduced by prefectural decree. Abstraction can even be prohibited. Restrictions vary according to use. For domestic water use, a general ban may be announced for certain uses, for example, watering the garden, filling swimming pools and washing cars. In the case of agriculture, the restrictions affect the weekly duration of irrigation, which is gradually reduced from 7 days to 1 day per week and may even be totally banned. 


\section{The organisation of water policing services}

\subsection{A transversal mission involving several government agencies}

In France, enforcing regulations is a strictly sovereign mission. Therefore, the government administrations alone are responsible for enforcement (no other actors are involved, e.g. user, NGO, local authorities). Since 1992, the prefect (the government representative at the county level) has been responsible for coordinating the water police.

For years, enforcement was carried out by several government agencies, with a different speciality field depending on the ministry they are affiliated to (industry, agriculture, environmental protection). This compartmentalisation impeded the effectiveness of enforcement because the different counties were simultaneously responsible for supporting economic development in a sector and managing its environmental impact. The 1992 Water Act unified the water policing service and placed it under the authority of the prefect. The coordination of the services greatly improved $^{67}$ in the early 2010s, partly in response to imperatives set by European directives $^{68}$.

Three main counties are now involved in water policing activities. These are supervised by the prefect (for the administrative police) and by the public prosecutor (for the judiciary police), and supported by the police:

- At the county level, the County Directorate for Territories and the Sea (DDTM) supervises the operational coordination of the different water policing services. This is an inter-ministerial county supervised by the prefect at the local level and the prime minister at the national level. The DDTM is responsible for regional development planning (urban, transport, housing and environmental issues). Water policing is coordinated by an inter-service mission for water and the environment (the MISEN). The DDTM is directly responsible for monitoring all the activities that are likely to harm water resources and natural environments (excluding installations classified for environmental protection, ICPE). Monitoring deals with quantitative management (surface or groundwater abstraction), as well as pollution from point sources (sewage treatment plants, livestock effluent) or non-point sources (nitrates and pesticides of agricultural origin).

\footnotetext{
${ }^{67}$ Decree $\mathrm{n}^{\circ} 2012-34$ of $11^{\text {th }}$ January 2012 relating to the simplification, reform and harmonisation of the environmental code for the provisions pertaining to the administrative police and the judiciary police. JORF $\mathrm{n}^{\circ} 0010$ of $12^{\text {th }}$ January 2012, page 564 .

68 In particular, Directive 2008/99/CE regarding the application of criminal law to environmental protection, which led to an organisational reform of the police, procedures and sanctions.
} 
- $\quad$ At the regional level, the regional environment agency (DREAL, which represents the Ministry of the Environment) coordinates the plan of action for the different counties responsible for the water police. It also inspects the facilities that constitute industrial pollution hazards (known as installations classified for environmental protection, ICPE in French).

- Lastly, the French agency for biodiversity (AFB, ex-ONEMA) is responsible for monitoring aquatic environments and fishing, in particular. As an independent public body, AFB staff are not accountable to the prefect. The AFB coordinates its action with the national agency for hunting and wildlife (ONCFS).

The average number of staff dedicated to water and environmental (widelife, fishing, hunting, etc) policing duties is 18.6 (full-time equivalent) per county (Legrand et al., 2015). However, only a fraction of them intervene in water management issues, often for part of their time.

\subsection{A dual mission: judicial and administrative enforcement}

The counties referred to in the previous section have two complementary police missions. It is important to note that the term police refers to "the power attributed to a person to restrict the liberty of individuals in order to prevent or repress disturbances to public order, public health and security, where necessary" (Boutelet et al., 2012). Water policing involves administrative and judicial police, who are responsible for prevention and enforcement, respectively.

For environmental issues, the administrative police are accountable to the prefect (the executive representative). For matters of quantitative groundwater management, policing involves examining, monitoring and reviewing declarations and authorisations for installations and abstraction. The administrative police set out the pumping limits to prevent damage to the water resource and aquatic environments. In the field, they check whether the works/installations/activities comply with the permits obtained and recommend administrative sanctions if an infraction is observed. The administrative police's mission is primarily conducted by the DDTM and, to a lesser extent, the DREAL. Table 23. 2 shows the administrative sanctions that can be imposed in the event of regulatory non-compliance. 
Table 23. 2: Administrative sanctions following an infraction (article L 216-1 of the environmental code).

\begin{tabular}{|c|c|}
\hline Infraction & Sanctions \\
\hline $\begin{array}{l}\text { Use of an unau- } \\
\text { thorised installa- } \\
\text { tion }\end{array}$ & $\begin{array}{l}\text { - A compliance notice. } \\
\text { - Failure to comply: installations are shut down or removed } \\
\text { and the site is restored. }\end{array}$ \\
\hline $\begin{array}{l}\text { Failure to com- } \\
\text { ply with regula- } \\
\text { tory provisions }\end{array}$ & $\begin{array}{l}\text { - An injunction demanding that work be undertaken within a } \\
\text { specified time. } \\
\text { If the work is not undertaken within the stated period, the } \\
\text { administrative police can proceed as follows: (a) order the } \\
\text { consignment of a sum to a public accountant, equal to the } \\
\text { cost of the work to be undertaken; (b) order that the work be } \\
\text { undertaken; (c) suspend the operations at the installation; (d) } \\
\text { impose a fine of } € 15000 \text { maximum and a daily penalty of } \\
€ 1500 \text { maximum; the fines and penalties are proportional to } \\
\text { the severity of non-compliance. }\end{array}$ \\
\hline
\end{tabular}

The judiciary police are responsible for identifying infractions, gathering evidence and finding the offenders. The public prosecutor deploys the judiciary police to perform these tasks, which are generally performed by environmental investigators from the AFB. They, in turn, are accountable to the public prosecutor. Environmental investigators are sworn officers or engineers that have some of the prerogatives of judiciary police. Most breaches involve no more than a compliance notice, which is referred to the public prosecution service. However, investigators can also search, seize documents, take water samples or other measures and conduct hearings with witnesses or plaintiffs. The public prosecutor has full discretion to decide on the appropriate prosecution in view of the elements provided by the judiciary police.

When the judiciary police identify a breach during their operations, a compliance notice is referred to the public prosecutor, who can proceed in several ways. If the evidence provided is judged to be insufficient, the case can be closed with no follow-up. The second possible option consists of a criminal fine, whereby the offender is fined and ordered to repair the damage caused by their breach ${ }^{69}$. The third option involves bringing the offender before a magistrate's court, in the case of an offence, or before a police tribunal, in the case of a contravention. If the infraction represents

${ }^{69}$ Although this approach should be limited to minor cases, reports suggest that it is used far too frequently (Court of Auditors annual report, Cour des comptes, 2010). 
a serious threat to the environment or public health, the public prosecutor can suspend the associated activity for a maximum duration of 3 months (interim measure).

Table 23. 3: Judicial sanctions that can be applied following an infraction (article L 173-1 to 173-12 of the environmental code).

\begin{tabular}{|c|c|}
\hline Infraction & Maximum sanctions \\
\hline Use of an unauthorised installation & $\begin{array}{l}€ 75000 \text { and } 1 \text {-year prison sentence ( } € 100 \\
000 \text { and } 2 \text {-year prison sentence in the case of a } \\
\text { breach following a refusal to grant authorisation) }\end{array}$ \\
\hline $\begin{array}{l}\text { Failure to respect a compliance no- } \\
\text { tice relating to an abstraction point }\end{array}$ & $€ 100000$ and 2-year prison sentence \\
\hline $\begin{array}{l}\text { Use of a facility without complying } \\
\text { with the provisions, causing substantial } \\
\text { degradation to flora, fauna or water }\end{array}$ & $€ 300000$ and 5-year prison sentence \\
\hline Obstructing the regulators & $€ 15000$ and 6-month prison sentence \\
\hline $\begin{array}{l}\text { In the event of a conviction for a } \\
\text { breach, the court can impose the follow- } \\
\text { ing additional sanctions }\end{array}$ & $\begin{array}{l}\text { Suspension of authorisation to use facilities } \\
\text { for the duration of } 1 \text { year maximum. } \\
\text { An injunction to restore the site and repair the } \\
\text { environmental damage caused; a fine of } € 3,000 \\
\text { per day after the deadline set for restoration is } \\
\text { reached }\end{array}$ \\
\hline $\begin{array}{l}\text { Additional possible sentences for } \\
\text { natural persons guilty of infractions }\end{array}$ & $\begin{array}{l}\text { The decision is published in medias. The ma- } \\
\text { terial involved in the regulatory breach is confis- } \\
\text { cated. The operator's activities are shut down ( } 5 \\
\text { years) }\end{array}$ \\
\hline
\end{tabular}

\section{The water police's methods of intervention}

\subsection{Limited monitoring pressure}

The administrative services responsible for water policing put little pressure on users. The national objectives stipulate that the services should devote $20 \%$ of their time to monitoring (preparation, execution, follow-up) and conduct a minimum of 400 inspections per year and per county (on- and off-site inspections), with an average national target of 600 per county. The investigations must focus on the geographic sectors and water management issues defined in the inter-institutional control plans. 
These goals may appear even less ambitious given that they cover all areas of environmental and water policy. Thus, in 2014, only $8 \%$ of the 25000 inspections conducted by ONEMA's 600 agents concerned quantitative resource management (surface and groundwater). Most of these inspections focused on monitoring aquatic environments (42\%) and water quality and pollution (38\%). Monitoring fishing represented $6 \%$ of inspections and monitoring species and natural habitats represented $5 \%$.

\subsection{An inter-institutional control plan}

As the state administration has limited means, the available resources are allocated to investigating priority issues and regions, according to a plan drawn up in each French county. The plan is established under the joint direction and supervision of the prefect (administrative police) and the public prosecution (judiciary police). It involves all the services and institutions that perform policing duties related to water and nature. It identifies the most effective investigative actions for meeting the objectives of protecting aquatic environments, habitats and species. In particular, the plan identifies the activities or installations, which exert major pressure on resources and natural environments, and which are generating a risk that the objectives of EU directives are not achieved. It determines the operational goals, namely, the number of investigations to be performed per administrative service, per theme and per sector, by specifying the orientation for each type of investigation (administrative police, judiciary police). The plan takes account of case history. Thus, controls are intensified where past activities have revealed frequent non-compliance depending on observed non-compliance. Lastly, random checks of installations or activities are performed (across all sectors and categories of person), to ensure that no one a priori escapes the control policy. One of the regulatory agencies is designated to organise and coordinate each type of inspection with associate services, if necessary.

Inspections related to abstraction are conducted at approximately $1 \%$ of abstraction points, all of which are located in sectors where there is pressure on the resource. The inspection usually involves checking the following points: (i) the presence of a meter; (ii) the existence of a record of meter readings dating back to when the authorisation was granted; (iii) whether the installation (well or borehole and drill head) complies with current regulations; (iv) the instantaneous pumping rate; (v) the period and periodicity of pumping; and (vi) the records of all the declarations of the volume abstracted that have been transmitted to the water police. 


\subsection{How controls are conducted}

The 2012-34 ruling of $11^{\text {th }}$ January $2012^{70}$ governs and defines the methods of inspection. Several reports published in the 2010s, as well as people that we surveyed in this study, stated that conducting inspections was difficult, especially in the agricultural sector (Legrand et al., 2015). Paradoxically, the counties where tension is the most acute are those with the fewest inspections. The regulators may be met with a very hostile reception. The people being inspected may express animosity or rudeness and verbal abuse, in some cases, or even death threats (Boizard et al., 2016). The AFB recorded 96 incidents (insults, threats, intimidation) that occurred during inspections in 2015. The situation is extremely difficult in south-west France, where agricultural representatives (unions) encourage farmers to refuse to cooperate during the inspections or even to prevent the regulator from carrying out their inspection. Thus, Boizard reports that farmers in the Lot-et-Garonne organise "reception committees" comprised of about 40 farmers, who support their colleague (the one being inspected) and put almost unbearable psychological pressure on the regulators (Boizard et al., 2016). For security reasons, inspections are systematically conducted by several officers. The regulator is generally unarmed (except the AFB personnel) but he may request the presence of the gendarmerie.

These tense situations can be explained, in part, by the fact that the farming profession does not understand the regulations or why they are justified, which undermines their legitimacy (Legrand et al., 2015). Farmers view water regulation as illegitimate because it pays disproportionate attention to the protection of environment, while totally neglecting what they think their mission is: to produce food to feed the world (Boutelet, 2014: p 149). Legrand et al. (2015) also suggest that the difficulty of applying the regulations may be because they are recent and are being applied to historically accepted uses. In this way, "the people inspected believe that they are within their rights, living on the land or farming it, to apply the law as they see fit".

Sometimes, farmers' hostility to controls can be explained by the high number of inspections imposed on their profession. Indeed, agriculture is subject to numerous and diverse environmental, labour and agro-food regulations, etc. This observation has led state services to coordinate the controls they perform in all fields relating to agriculture.

\subsection{Coordination between the water police and the judicial system}

In the early 2010 s, several reports showed that many of the compliance notices served by the water police were not followed up by the public prosecutor ( $91 \%$ in 2008 , for example). Several reasons have been put forward to explain this situation

\footnotetext{
${ }^{70}$ Published in the JORF on $12^{\text {th }}$ January 2012.
} 
(Boutelet, 2014; Barone, 2016; Barone, 2018): court congestion; the magistrates' lack of technical expertise, since they generally have little training in environmental $1 \mathrm{aw}{ }^{71}$; and the water police officers may not prepare the cases properly. Nonetheless, the lack of human resources in the judicial system seems to be the primary factor, as Marguerite Boutelet illustrates when she quotes a magistrate, who explains: "We are overloaded with work. When young girls are being raped, when drug dealers must be prosecuted, fish survival can wait" (Boutelet, 2014: p. 150).

Between 2012 and 2015, the state took steps to improve the coordination between the actions performed by the water police and the public prosecutor (MEDDTL, 2012; Ministère de la Justice, 2015; Barone, 2018hed). At the prosecution level, referral magistrates were appointed in the environmental field. They were informed about the economic issues associated with environmental protection and given the responsibility of coordinating the actions performed by the water police and the public prosecutor. Coordination was formalised by establishing a protocol, which defines the operational arrangements for legal action, from the field to the tribunal. In $2015,78 \%$ of counties had a memorandum of understanding signed by the water policing services and the public prosecution service (MEEM, 2016) ${ }^{72}$.

The established protocols have several goals. First, they strive to clearly define how to conduct inspections and open an enforcement case to minimise the risk of procedural defect. They also seek to limit the number of cases presented to the public prosecutor, by selecting the most serious. Therefore, the water police are invited to apply sanctions progressively. The gradual approach (shown in Figure 23. 2) involves providing an administrative response to all the regulatory breaches that have not caused environmental damage (1 in the figure). This response should be incremental: (i) compliance notice, specifying the actions to be undertaken in order to comply within a specified deadline; (ii) administrative sanctions in the event of nonexecution (fine, suspension of activity, etc.); and referral to the public prosecutor for criminal prosecution, as a last resort. In the event that the breach caused damage that is reparable (2), the ministry recommends recourse to a criminal fine ${ }^{73}$. This option is requested and approved by the prosecutor. The administrative authority prepares the settlement. Criminal fines can only be used in cases where the potential sanction is less than a 2-year prison sentence. When the law calls for sanctions exceeding a 2-year prison sentence, criminal sanctions must be applied, for example, in the event of a repeat offence or when the breach is deliberate

\footnotetext{
${ }^{71}$ In France, there are no specialised judges, offences that have an impact on nature and the environment are dealt with by generalist magistrates and jurisdictions.

72 Barone (2018) has shown that these memorandum are only efficient if there is a true commitment from their signatory to implement them, which is not systematically the case.

73 The Court of Auditors criticised the fact that recourse to criminal fines was too systematic. According to Barone (to be published) and van Bosterhaudt (2014), recourse to criminal fines encourages economic actors to commit environmental crimes because the financial profit generated by non-compliance with the regulatory constraint is far greater than the fine imposed in the event of a criminal fine.
} 


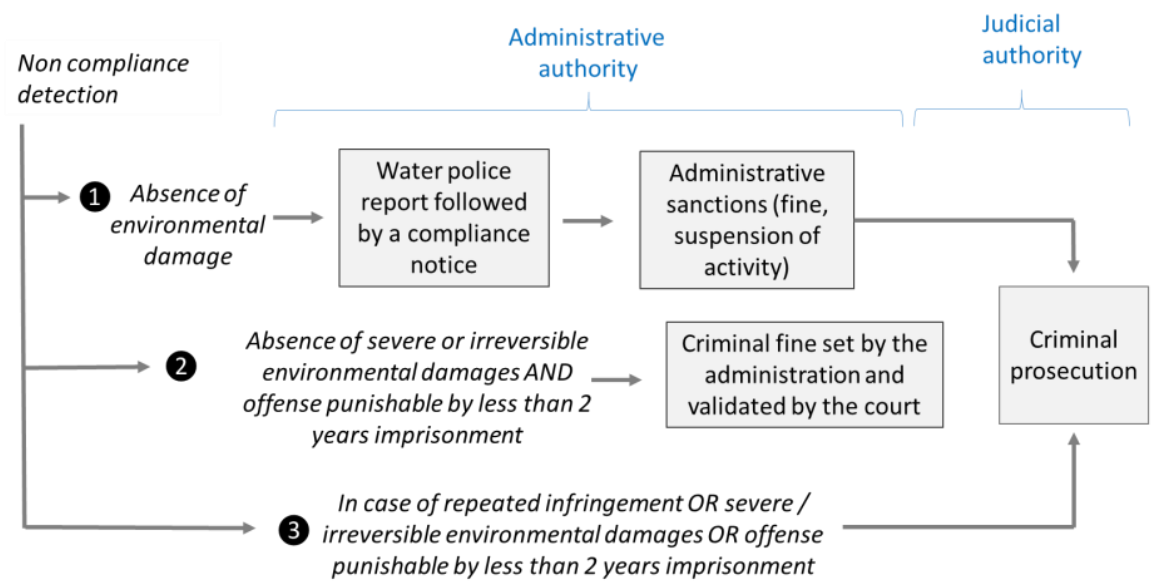

Figure 23. 2: The gradual approach to sanctions recommended by the Ministry of Ecology (Executive Order of 20 ${ }^{\text {th }}$ October 2014).

\section{Level of compliance: observations and inter- pretation}

\subsection{Statistical information on compliance}

Detailed data relating to the inspections carried out by the water police, as well as the nature of the infractions observed, are not made public by the state services. This rules out the possibility of statistical analyses. The only available data, produced separately by the Ministry of the Environment and the French agency for biodiversity, are shown in Table 23. 4 Table 23. 5and Table 23. 5. These data show that between 20 and $37 \%$ of inspections detect non-compliance. A substantial number of cases of non-compliance are infractions. They are sanctioned by compliance notice and referred to the public prosecutor. The proportion of violations observed by the AFB is higher than that observed by the DDT. This reflects the fact that the AFB primarily conducts field visits as part of its judiciary police duties. These figures should be considered with caution because they concern all the inspections undertaken relating to the management of water resources, aquatic environments and nature. There is no way of identifying which inspections concern quantitative water management, let alone groundwater management. 
Table 23. 4: Evolution in the number of inspections where non-compliance is detected and infractions observed by AFB agents (named ONEMA before 2016)

\begin{tabular}{|c|c|c|c|c|c|}
\hline & $\begin{array}{l}\text { Inspections under- } \\
\text { taken }\end{array}$ & \multicolumn{2}{|c|}{ Non-compliance $*$} & \multicolumn{2}{|c|}{ Infractions $* *$} \\
\hline 2016 & 19500 & 7215 & $(37 \%)$ & 2500 & $(34 \%)$ \\
\hline 2015 & 22833 & 7535 & $(33 \%)$ & 3000 & $(40 \%)$ \\
\hline 2014 & 25500 & 8415 & $(33 \%)$ & 7405 & $(88 \%)$ \\
\hline 2013 & 25200 & 8316 & $(33 \%)$ & 5112 & $(61 \%)$ \\
\hline 2012 & 22932 & 8485 & $(37 \%)$ & 5618 & $(66 \%)$ \\
\hline
\end{tabular}

* Number of inspections where non-compliance is detected and global level of non-compliance (\%).

**Number of infractions as a percentage of the number of cases of non-compliance.

Source: ONEMA 2010 to 2015; AFB (2016).

Table 23. 5: Evolution in the number of inspections involving the administrative and judiciary police undertaken by the DDTM, the level of compliance and infractions reported.

\begin{tabular}{|c|c|c|c|c|c|c|c|}
\hline & \multicolumn{6}{|c|}{ Administrative police } & \multirow{3}{*}{$\begin{array}{l}\text { Judiciary } \\
\text { police } \\
\text { Infrac- } \\
\text { tions }\end{array}$} \\
\hline & \multicolumn{2}{|c|}{$\begin{array}{l}\text { Inspections } \\
\text { undertaken }\end{array}$} & \multicolumn{3}{|c|}{$\begin{array}{l}\text { Inspections that detect } \\
\text { non-compliance }\end{array}$} & \multirow{2}{*}{$\begin{array}{l}\text { Adminis- } \\
\text { trative proce- } \\
\text { dures }\end{array}$} & \\
\hline & $\begin{array}{l}\text { Off } \\
\text {-site }\end{array}$ & $\begin{array}{l}\text { On- } \\
\text { site }\end{array}$ & $\begin{array}{l}\text { Off } \\
\text {-site }\end{array}$ & $\begin{array}{l}\text { On- } \\
\text { site }\end{array}$ & $\begin{array}{l}\text { To- } \\
\text { tal }\end{array}$ & & \\
\hline $\begin{array}{r}2 \\
015\end{array}$ & $\begin{array}{l}25 \\
247\end{array}$ & $73^{19,2}$ & $47^{3,9}$ & $29^{5,1}$ & $\%^{20}$ & $\begin{array}{l}4,180 \\
(46 \%)\end{array}$ & $\begin{array}{l}1,190 \\
(3 \%)\end{array}$ \\
\hline $\begin{array}{r}2 \\
014\end{array}$ & $\begin{array}{l}33 \\
361\end{array}$ & $43^{22,0}$ & $63^{4,2}$ & $89^{5,8}$ & $\%^{18}$ & $\begin{array}{l}5,050 \\
(50 \%)\end{array}$ & $\begin{array}{l}1,330 \\
(2 \%)\end{array}$ \\
\hline $013^{2}$ & $\begin{array}{l}33, \\
694^{3}\end{array}$ & $55^{37,3}$ & $08^{4,2}$ & $35^{9,1}$ & $\%$ & $\begin{array}{l}4,693 \\
(35 \%)\end{array}$ & $\begin{array}{l}6,169 \\
(9 \%)\end{array}$ \\
\hline $012^{2}$ & $142^{32}$ & $88^{29,1}$ & $04^{3,4}$ & $40^{9,5}$ & $\%^{21}$ & $\begin{array}{l}6,147 \\
(47 \%)\end{array}$ & $\begin{array}{l}7534 \\
(12 \%)\end{array}$ \\
\hline $\begin{array}{r}2 \\
011\end{array}$ & $\begin{array}{l}41 \\
737\end{array}$ & $83^{38,7}$ & $\begin{array}{l}12 \\
537\end{array}$ & 361 & $\%^{28}$ & $\begin{array}{l}10,493 \\
(46 \%)\end{array}$ & $\begin{array}{l}8157 \\
(10 \%)\end{array}$ \\
\hline
\end{tabular}




\subsection{Type of infractions observed}

The results of the survey conducted by the authors helped identify the characteristics of the main infractions observed relating to the management of groundwater abstraction.

Overall, compliance with the regulations is considered to be a genuine problem in 11 out of 17 counties. As far as volumetric management is concerned, the two main problems are: the absence of flow meters (four counties) and the lack of meter readings or unsatisfactory records (six counties, see Figure 23. 3). Compliance with the authorised volumes is considered problematic in three counties. The inspectors claim not to have sufficient information to determine how often the meters may be tampered with. The use of wells and boreholes for irrigation, which are not declared for that purpose, is considered significant in three counties. Other cases of noncompliance have also been described relating to borehole construction, for example (no drill head cover). Compliance with the temporary restrictions on water use is not perceived as a problem.

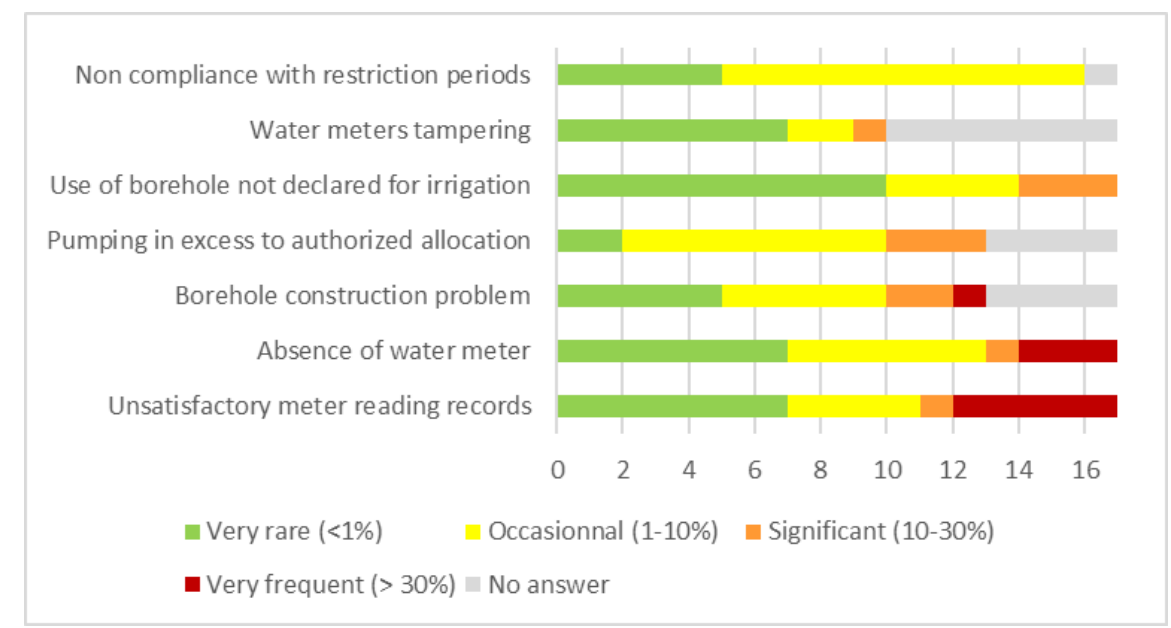

Figure 23. 3: Frequency of non-compliance problems as perceived by regulators interviewed in 17 counties.

The situation varies depending on the counties. In order to visualise the differences, we devised an indicator of compliance, incorporating an assessment of the frequency of the seven infractions described in Figure 23. 3. The indicator has a value of 1 , if all seven of the infractions are considered very frequent; and 0 , if no infractions are reported. Figure 23. 4 is a simplified representation of the diversity of situations. The first group of counties (eight counties) is characterised by the relative absence of problems (the indicator $=0.07$ and no infraction is considered "frequent or very frequent"). In the second group (four counties), the indicator has 
an average value of 0.21 , with 1.25 infractions considered very frequent. Lastly, the third group (five counties) includes the counties where almost three out the seven infractions are considered very frequent and the indicator has a value of 0.41 . These results (Figure 23.4) illustrate the diversity of situations as perceived by the water police. It is only a qualitative indicator, which is not based on a precise measure of the number of infractions.

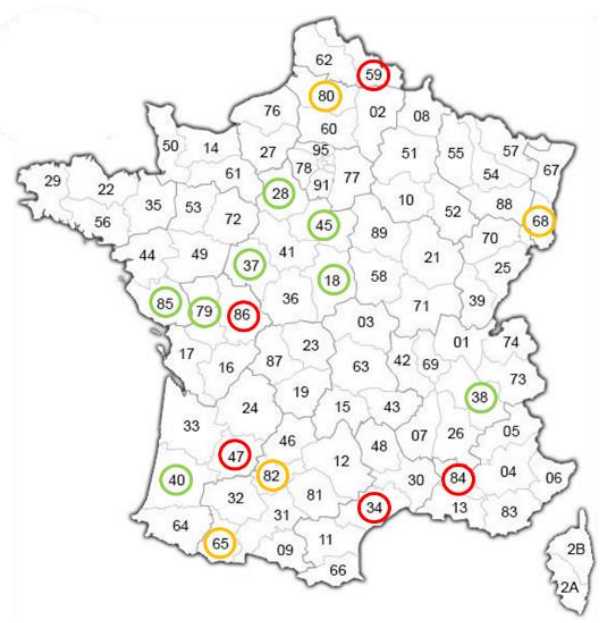

\begin{tabular}{|l|l|l|l|}
\hline & $\bigcirc$ & $\bigcirc$ & $\bigcirc$ \\
\hline $\begin{array}{l}\text { Average value of } \\
\text { the compliance } \\
\text { indicator }\end{array}$ & 0.07 & 0.21 & 041 \\
\hline $\begin{array}{l}\text { Number of } \\
\text { infractions } \\
\text { considered as } \\
\text { frequent }\end{array}$ & 0 & 1.25 & 2.8 \\
\hline $\begin{array}{l}\text { Number of } \\
\text { counties }\end{array}$ & 8 & 4 & 5 \\
\hline
\end{tabular}

Figure 23. 4: Classification of counties into three groups according to the intensity of problems of compliance (results of the survey).

\subsection{Factors that determine non-compliance}

The survey also shed light on the factors that determine regulatory compliance or non-compliance in the different counties surveyed (see Table 23. 4 and Table 23. $5)$. In the case of non-compliance, the water police officers consulted in the 17 counties studied agree on the observations below.

First, the economic pressure facing farmers can explain the majority of breaches related to water abstraction (12 out of 15 counties, see Figure 23. 5). This is particularly pertinent for farmers, who produce high added value crops such as seeds, fruit and vegetables under contract for the industry. It is also the case for dairy producers whose production depends on irrigated fodder (11/13).

In addition, the level of financial sanctions recommended by law is too low to be an incentive (11/17). The probability of an inspection remains very low (12/17). The fact that criminal sanctions are not systematically applied when a breach is reported is also perceived as a factor that may explain the regulatory non-compliance observed in 5 out of 15 counties. 
Interviewees also report that, in a minority of counties, the social climate in the agricultural sector does not encourage regulatory compliance. Farmers who breach the regulations are not stigmatised by their peers when they receive a compliance notice $(8 / 15)$. In most counties, there is no social pressure within the agricultural sector to encourage self-monitoring. A water police officer working in a county in the south-west explained that offenders derive a certain pride or social prestige from being booked. "It's a bit like in the suburbs, they are proud to be against the water police. People used to hide it, but now they show it". Farmers seem unperturbed by the risk of a confrontation with the civil society (7/16).

Water users challenge the legitimacy of the regulations (11 out of 16 counties). The regulations are perceived as giving too much priority to environmental protection, to the detriment of the productive use of water resources (farming, in particular). The agricultural sector is reluctant to let a water resource "flow to the sea", when it could be used to produce food to feed the world. Farmers do not always understand how the regulations are applied, particularly, when restrictions of use are applied incrementally within the same county. This observation reflects $\mathrm{M}$. Boutelet's analysis (2014).

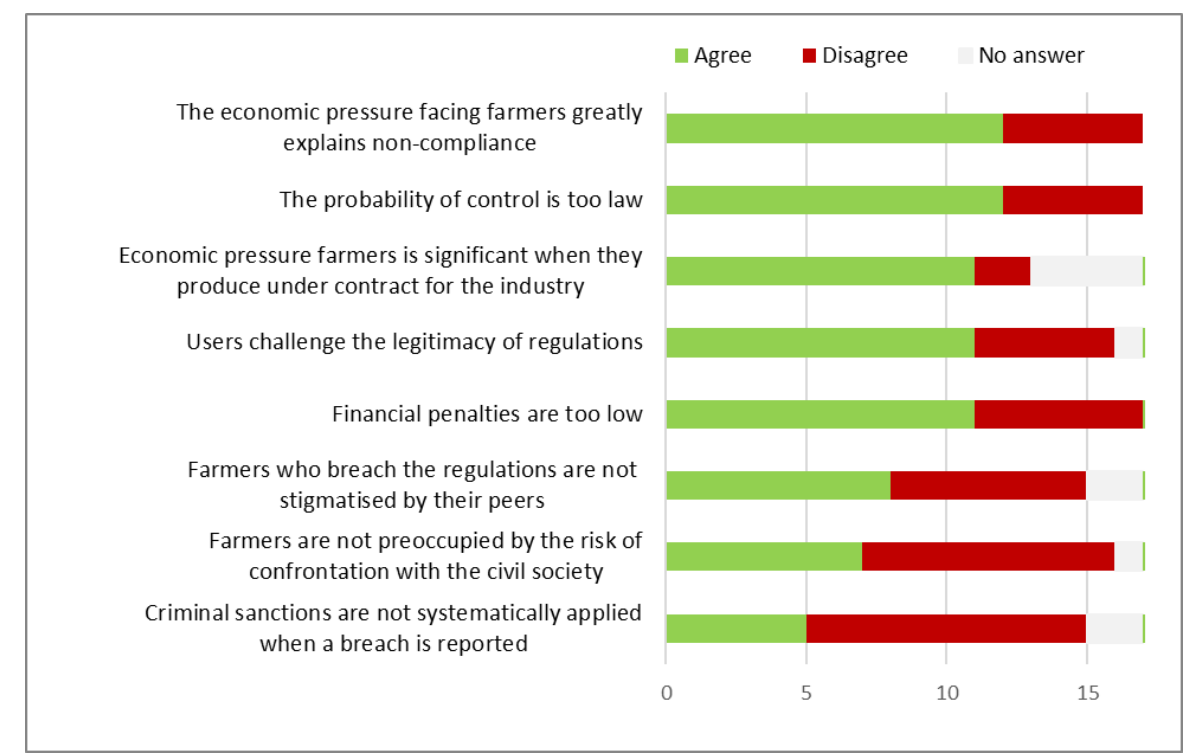

Figure 23. 5: The main factors that explain situations of regulatory non-compliance (results of the survey with the enforcement officers from 17 counties). 


\subsection{Factors that facilitate compliance}

The agents surveyed agree with the following observations regarding factors that facilitate compliance (see Figure 23. 6). Overall, farmers are aware of the regulations that they must comply with (12/15), notably, because the professional farming organisations and state services make an effort to inform them. Generally, farmers have the necessary available resources (time, money and advice) to comply (9/16) because the professional organisations (Chamber of Agriculture, collective management organisations or OUGC) and the state services can provide support (14/15).

In addition, farming representatives encourage farmers to comply with regulations (13/15), except in a few counties, where the profession has a more ambiguous position and may even overtly encourage disobedience ${ }^{74}$.

The water police's gradual approach to sanctions also facilitates regulatory compliance (13/15). Indeed, the aim of prioritising pedagogy over punishment is to improve the compliance rate. The coordination between the water police and the public prosecutor is also helpful (9/13).

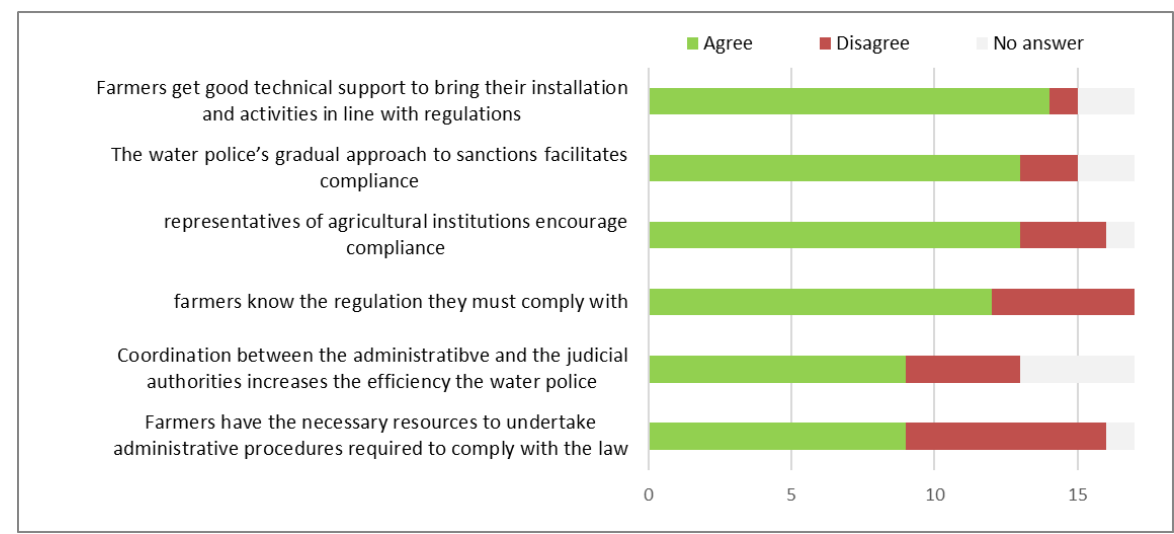

Figure 23. 6: Main factors that facilitate compliance according to the enforcement officers surveyed.

\subsection{A behavioural typology}

The survey also examined whether there are types of users (profiles), who may or may not comply with regulations. Generally, the survey suggests that it is difficult to establish a typology of offenders, even if non-compliance may reflect different types of rationale (Table 23.6).

\footnotetext{
74 In 2013, ONEMA reported 19 public statements expressing offensive comments about the water police, most of which came from professional farming organisations (Legrand et al., 2015).
} 
Table 23. 6: Different types of rationale that could lead to regulatory non-compliance.

Type of rationale

Ill-informed small farmer, lacking the resources to comply

Farmer involved in professional organisations, who has political support to defend his case in the event of a conflict with the administration

Small farm, whose economic survival would be at risk in the event of a water restriction: market gardening, livestock production

Individual who considers that the regulations are illegitimate and decides to resist by not complying

Farmer who resists all regulations and is prepared to contravene if noncompliance costs less than compliance

\section{Determinant}

Lack of information \& support

Political power and capacity to influence administrations

Economic pressure

Ideological and political motivation

Maximum profit seeking
Trigger for action

Information about the procedures

Impartial application of sanctions prescribed by the state

Diagnosis to reduce economic vulnerability to water shortage

Extended information about water management issues

Strict application of sanctions, including criminal sanctions

\section{Improving the effectiveness of law enforce- ment agencies}

\subsection{The main difficulties reported by the law enforcement officers}

The survey also focused on the main difficulties that the enforcement officers encounter while performing their duties (Figure 23. 7). Some difficulties are mentioned in all the counties, while others are more specific to certain regions.

The main difficulty common to all the counties is the lack of human resources for carrying out inspections. It is considered as a major obstacle in 8 out of 17 counties, especially in counties with large areas of agricultural land ${ }^{75}$. As the probability of inspection is very low, a sense of impunity has developed among users who do not comply with the regulations, while those who do comply feel that the situation is unfair or unjust.

\footnotetext{
75 According to the Court of Auditors, the number of inspections undertaken by the water and environmental police was reduced by half between 2011 and 2015 (Cour des comptes, 2017).
} 
The lack of modern technology for inspection is also considered to be a limiting factor $(8 / 15)$ or even a major obstacle $(2 / 15)$ for effective water policing. Thus, during a field inspection, the use of tablets (with an Internet connection) would provide regulators with access to all the information relating to the abstraction point, the history of use, crop data, etc. The use of airborne methods, such as ultra-light aircraft or drones would mean that compliance during temporary restrictions on water use could be checked. Similarly, when the manager of an irrigation system installs smart meters (see Chapter 18), the water police should be able to access data in real time, which would make their action more effective. Lastly, some of the enforcement officers surveyed suggest using transparency as an incentive. This would entail making water abstraction data available on the Internet to encourage self-monitoring among users.

The majority of police services also mention that political interference prevents them from doing their job properly. This interference is considered to limit the water police's effectiveness in 11 counties. It is seen as a major obstacle in four counties. The nature of the political interference is roughly as follows: the Chambers of Agriculture and the farming unions ask the prefect to ensure that when the water police perform their duties, they take economic issues into account and do not sanction infractions committed in years that are difficult for climatic reasons. The prefect may be sensitive to this kind of request if the local social climate is tense and the agricultural sector could implicitly threaten to disturb public order by organising demonstrations. The prefect can ask the water police to refrain from serving a compliance notice, except in cases where there is evident abuse. Therefore, the application of the regulations is subject to negotiation between the various social groups. Interference of this type has an adverse impact in the long term. Farmers (users) expect support from their representatives and do not comply scrupulously with the regulations (especially the authorised volumes). This is detrimental to the water police's credibility and may encourage other users to flout the regulations. This was observed during the survey and reflects Sylvain Barone's work (2018), which shows that the state prefers negotiating with economic actors, rather than applying sanctions. This demonstrates that economic development and the preservation of social peace have priority over environmental protection.

Other difficulties were mentioned during the survey, although they did not concern all the counties. A major problem in one county (only mentioned in eight others) is that the sanctions imposed lack credibility. This is largely due to the high incidence of cases that are closed by the public prosecution with no further action. The hostility of users towards the enforcement officers is mentioned in seven counties. In one county it represents a major obstacle because it means several officers must be present at each inspection, which reduces the number of inspections carried out. The existence of a dominant lax culture (or weak social norm) is mentioned in five counties. However, dysfunctions involving the water police are seldom mentioned, be it the way inspections are planned and undertaken or the coordination between the different police services. 


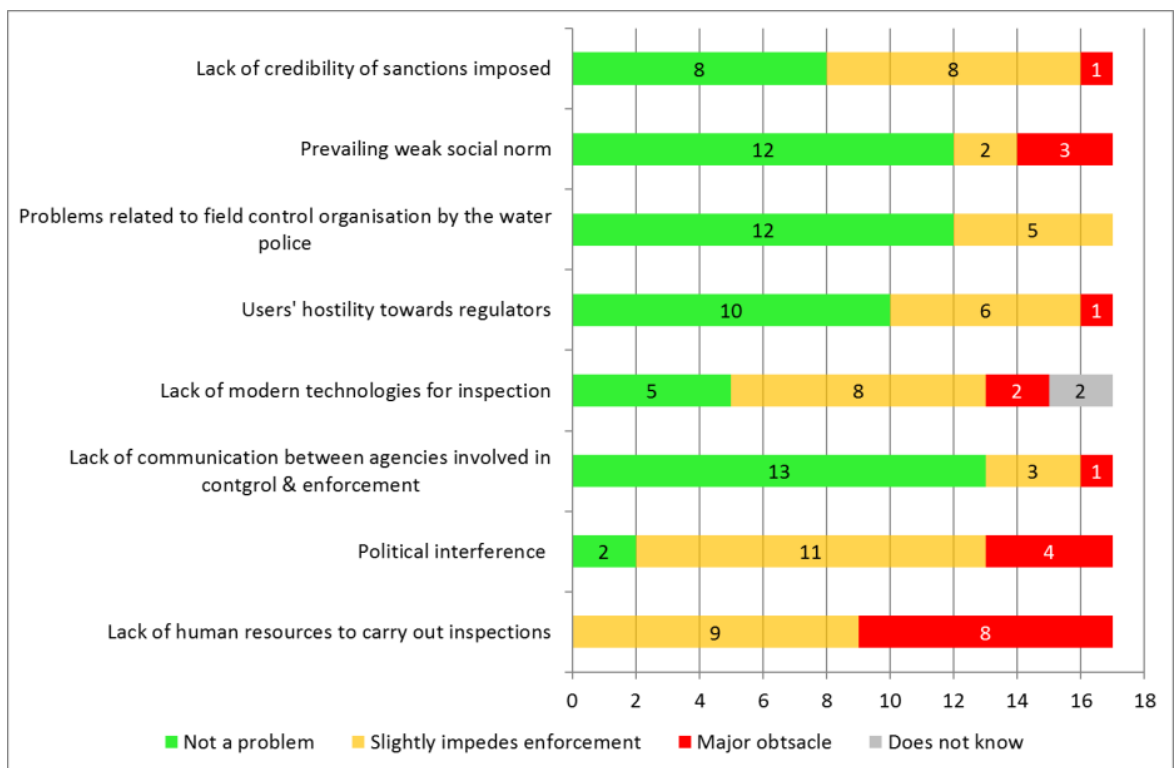

Figure 23. 7: The main difficulties encountered by the water police during operations.

\subsection{Past and future evolution}

In over half of the counties (eight), the officers surveyed estimate that the situation has improved significantly in the last 10 years. This is primarily due to improvements in the services' internal procedures: the different services have pooled their resources; intervention protocols have been established; communication with the public prosecution has improved. The improvement is also the result of pedagogical action that targets different audiences: users, the Chambers of Agriculture, the prefect and political decision makers. Clearly, the fact that pedagogy was preferred to sanctions means that the police are regarded as partners, who can help the users comply.

On the contrary, two counties consider that the situation is worse due to a combination of three factors. The first relates to the state's capacity of action, which seems to be eroding: fewer resources are allocated to sovereign missions; political interference has increased; and certain responsibilities have been delegated to the users, with the creation of the collective management organisations, the OUGC (see Chapter 3). The second factor is of an economic order: the agricultural sector is in crisis and farms' economic survival takes precedence over environmental protection. Lastly, climate change exacerbates the problems of shortage, especially during the summer period.

The vision of the future is more contrasted. The majority of officers surveyed are confident about the future and in the capacity of the state services to adapt to the 
current changes, particularly, climate change. Several factors are mentioned: (1) the increase in the frequency of crises (drought) is seen as a positive factor because it helps raise awareness of the issues among users and other actors in civil society, such as environmental protection organisations. (2) Setting up the OUGC (delegated by the state to share the resource), is also seen as a factor that encourages the farming profession to take responsibility. (3) Overall, the institutions responsible for managing water at the level of river or groundwater basins, especially the organisations in charge of the local water management plans (SAGE), will have more technical, financial and legal resources to put pressure on users that fail to comply with regulations. (4) The state is constantly improving service coordination, which could compensate for the small number of $\operatorname{staff}^{76}$. (5) The adoption of new technology (e.g. smart meters) should also facilitate inspections and make it easier to apply regulations. (6) The users are gradually improving the efficiency of their irrigation techniques, which means that the volume required per hectare can be reduced. (6) Lastly, the construction of reservoirs for storing excess water in the winter will help reduce conflicts in the summer (see Chapter 18).

Several agents surveyed are more pessimistic about how compliance will evolve in the future. In their view, the sustainable water resource management policy is bound to fail because of the reduction in the human resources allocated to monitoring. In addition, they consider that the volumes allocated for abstraction are overoptimistic, often as a result of pressure from the agricultural profession (see Chapter 11). This will inevitably cause environmental crisis situations, which are likely to be more frequent as a result of climate change. The state will no longer have the wherewithal to enforce the rules for crisis management (temporary restrictions of use); the crises will be too frequent and applying the regulations would threaten the survival of a large number of farms. Society may well accept giving priority to economic activities and employment, to the detriment of protecting water resources.

\section{Conclusion}

The implementation of a quantitative management policy for water resources implies that the state has the capacity to enforce the often complex regulatory provisions on thousands of users: users that are scattered over vast regions and whose behaviour is not easy to discern. This can only be achieved if the state allocates considerable human, technical and financial resources to water policing. The results of the survey presented in this chapter show that this is not the case, even in a country like France, which has sufficient economic resources and a multisecular tradition of state intervention in water management.

\footnotetext{
${ }^{76}$ See Jevakhoff et al. (2018) for a discussion on the need to rethink the spatial distribution of police staff at the AFB and ONEMA across French territory.
} 
The primary lesson drawn from this survey is that it will take years or even decades to make groundwater users comply with regulations. This is because regulations restrict the use of a resource, which users have considered to be freely accessible for years. Users will only comply with regulations if they fully understand their justification and are convinced that they are genuinely in the public interest. This requires political discussion, which has not necessarily occurred in all the French counties analysed in this survey. Nevertheless, the survey shows that there are less serious problems of compliance in regions where quantitative management was set up over 20 years ago (Clain basin, Beauce aquifer, Poitevin marshlands ${ }^{77}$ ) in comparison to the south-west, where it is relatively recent. When regulations are enforced, the users should also be trained in the procedures to apply. French law states that ignorance of the law is no excuse. Yet, it is common sense to suggest that the state should be responsible for training users. Therefore, the water police's primary mission is pedagogical. The punitive approach is only applied gradually over time.

The second lesson is that it is harder to convince people of the value of environmental protection compared to other issues, which are considered more fundamental by society as a whole. To quote M. Boutelet (2014: p. 150), local actors "are vaguely aware of the need to protect the environment but not to the point of regarding environmental damage as the violation of a fundamental value, such as damage to private property, for example, theft". This raises the question: are the recently established user groups (OUGC, see Chapter 3 ) capable of implementing the regulations? The transfer of certain state responsibilities (for example, resource allocation) begs the question: would it not be better to strengthen the state's capacity to control and apply sanctions in parallel?

The third lesson drawn from the survey is related to how the water police are organised and how their action is coordinated with that of the judicial system. The French experience demonstrates the advantage of this type of coordination when it comes to: targeting the main local water management issues; developing a common culture shared by magistrates and water police officers; and defining the methods for field intervention and case preparation. Administrative sanctions and criminal fines are applied more frequently than other penalties in order to improve user compliance. Criminal sanctions, which have a moral dimension, are only applied in exceptional cases. They should be exemplary. Indeed, the credibility of public action depends on it. This would also help avoid overloading the legal system, which is already struggling in France, as is the case in many other democracies.

The challenges of compliance and enforcement are by no means specific to France, as shown in chapters 22, 27 and 29, which deal with the issue in relation to Australia, Chile and Morocco.

\footnotetext{
${ }^{77}$ Departments (counties) 18, 28, 37, 45, 79, 85 and 86 in Figure 23. 4.
} 


\section{References}

Barone, S., 2016. Comment la Justice traite les dommages écologiques : une sociologie des acteurs judiciaires face aux atteintes à l'eau et aux milieux aquatiques. Final report. Montpellier: Irstea, $46 \mathrm{p}$.

Barone, S. (2018). L'impunité environnementale : l'Etat entre gestion différencielle des inégalismes et désinvestissement global. Champs Pénal. Vol XV.

Boizard, P., Garcin, M.-L., M Vol XV.enager, T., Tosi, J.-C., 2016. Audit de la mise en oeuvre des politiques de l'eau et de la biodiversité dans le département de Lot-et-Garonne. Paris: Ministère de l'Environnement, de l'Energie et de la mer et Ministère de l'Agriculture, de l'AgroAlimentaire et de la Forêt, 139 p.

Boutelet, M (2014) Polices de l'eau et ordre public écologique, valeurs exprimées, valeurs protégées. Droits et Cultures, vol 68: 143-163.

Boutelet M., Brun A and Van Bosterhaudt P. (2012) "La police de l'eau. L'autre versant de la politique de l'eau en France" in Brun and Lasserre (dir.), Gestion de l'eau, approche territoriale et institutionnelle, Presse de l'Université du Québec.

Cour des Comptes, 2010. Les instruments de la gestion durable de l'eau. Paris: Cour des comptes. $39 \mathrm{p}$.

Cour des comptes (2017). Les services déconcentrés de l'Etat: clarifier leurs missions, adapter leur organisation, leur faire confiance. Paris. 269 p.

Jevakhoff, A., Barthod, C., Cartier, J., Delaunay, A., Lavarde, P., 2018. L'avenir des opérateurs de l'eau et de la biodiversité. Inspection Générale des Finances and CGEDD, p. 27.

Legrand, H., Rébeillé-Borgella, E., Chabrol, D., Flam, G., Marchal, Y., Soulié, M.-C., (2015). Evaluation de la police de l'environnement. Paris: rapport interministériel, Ministères chargés de l'Ecologie, de la justice, de l'intérieur, et de l'agriculture, $160 \mathrm{p}$.

Ministère de l'Écologie, de l'Énergie, du Développement durable et de l'Aménagement du territoire - MEDDTL (2009). Police de l'eau - rapport d'activité 2008. Paris: Ministère de l'Écologie, de l'Énergie, du Développement durable et de l'Aménagement du territoire, Bureau des polices de l'eau et de la nature, $19 \mathrm{p}$.

Minsitère de la Justice (2015) Circular $n^{\circ} .2015-04$ of $21^{\text {st }}$ April 2015, relating to: les orientations de politique pénale en matière d'atteinte à l'environnement. Journal Officiel du Ministère de la Justice, 30 April 2015. 30 p.

Ministère de l'Environnement, de l'Energie et de la Mer (2016) Rapport d'activité des services déconcentrés 2015. Gestion des ressources naturelles. Paris. 39 p.

Simoni, M-L., Perriez, F., Berriat A., Delbos, V., Maziere B., Tetart S., Bourgau J-M., Guth M-O and Verrel J-L. (2005). Renforcement et structuration des polices 
de l'environnement. Paris: rapport interministériel des ministères chargés de l'Intérieur, de l'Equipement et de l'aménagement du Territoire, de l'agriculture, de la justice et de l'Ecologie, $70 \mathrm{p}+$ annexes.

ONEMA, 2011. Les temps forts 2011 de l'Onema. 48 p. http://www.onema.fr/sites/default/files/images/temps-forts-2011.pdf (accessed 14/09/2018)

ONEMA, 2012. Les temps forts 2012 de l'Onema. 25 p. http://www.onema.fr/sites/default/files/pdf/Onema-Temps-forts.pdf $\quad$ (accessed 14/09/2018)

ONEMA, 2013. Les temps forts 2013 de l'Onema. 52 p. http://www.onema.fr/sites/default/files/images/les-temps-forts-2013.pdf (accessed 14/09/2018)

ONEMA, 2014. Les temps forts 2014 de l'Onema. 52 p. http://www.onema.fr/sites/default/files/images/temps-forts2014.pdf $\quad$ (accessed 14/09/2018)

Van Bosterhaudt, P. (2014). Les valeurs des polices de l'eau. Efficacité du droit pénal de l'environnement à l'épreuve de la protection de l'eau et des milieux aquatiques? Droit et cultures. Revue internationale interdisciplinaire, (68), 81-142. 